\title{
THE RIGHT TO A FAIR CIVIL TRIAL: THE DUTIES OF LAWYERS AND LAW STUDENTS TO ACT PRO BONO
}

\author{
JASON BRICKHILL*
}

\begin{abstract}
Vast numbers of civil litigants in South Africa go unrepresented and unadvised during proceedings which affect their most significant interests. Section 34 of the Constitution guarantees a fair civil trial. While s 35 , which entrenches the right to a fair criminal trial, expressly confers a right to legal representation in criminal matters, at least in some cases, s 34 is silent on what a 'fair' civil trial requires. This article considers the scope of the right to a fair trial in civil matters, sketches the history of diverse attempts to provide civil legal aid to the poor and analyses the effectiveness of the different approaches. Against a background of glaring statistics about the cost and availability of free representation, and on numbers of law students, recent graduates and practising attorneys, it considers the feasibility of compulsory programmes for the provision of civil legal aid by the state and the private sector.
\end{abstract}

\section{INTRODUCTION}

The 1996 Constitution envisages massive changes to South Africa's socioeconomic landscape, specifically aiming to achieve substantive equality by bringing the law to bear on apartheid's iniquitous legacies. In this article I tackle the issue of civil legal aid in South Africa, which is potentially the key instrument for achieving the change envisaged in the Bill of Rights, but has for too long been neglected both as an academic subject and as a political objective.

I will consider the relevant constitutional provisions, and ask what guarantees of legal aid the Constitution provides. I will trace the historical attempts by state and non-governmental actors to provide legal aid, leading up to the current position. I question the continuing emphatic prioritisation of criminal legal aid over civil, particularly in the state sector. At present, there is a group that falls outside the available civil legal aid resources but cannot afford private legal assistance. In

\footnotetext{
* Candidate Attorney, Johannesburg. I am grateful to the University of Cape Town, and the Department of Public Law in particular, for supporting the writing of this article and funding some of the research involved. In particular, I thank Professor Christina Murray, who supervised this research. This paper has also benefited from comments on drafts from members of the Public Law Research Focus Group at UCT and Professor Lee Anne de la Hunt, Director of the UCT Legal Aid Clinic. The article was further edited during 2004, when I was a Law Clerk to Justice Kate O'Regan of the Constitutional Court.
} 
order to serve this broad group, which is largely the working poor, lower middle class and parts of the rural population, significant policy reform is necessary. As the state's resources are stretched, the private sector and the legal profession could provide the human resources necessary: admitted attorneys, law students and graduates. Finally, I will consider the possibility of compulsory programmes for the provision of legal aid by these groups.

\section{Constitutional ConTeXt}

The simple reality of South African society today is that the majority of the population lives in conditions of stark poverty. For any of the constitutional promises to bear fruit, access to civil justice is a simple prerequisite. This involves creating conditions for genuine legal equality in the procedural and administrative aspects of the legal system. Such legal equality has intrinsic value, as it reflects the notion of the equal dignity of persons. Part of the means to achieve this end (legal equality and fairness) is the provision of legal aid. However, as Allen argues, the protection of civil liberties, including securing 'fair' civil hearings, should not be the only goal of legal aid. It should also be understood as a way to enforce substantive equality rights and promote constitutional guarantees. ${ }^{1}$

Legal aid, therefore, has an important role to play in facilitating the enforcement of substantive constitutional rights. This is well illustrated by the facts of a recent case decided by the Constitutional Court, Jaftha $v$ Schoeman. ${ }^{2}$ The two applicants were unemployed women, with few assets, living in Prince Albert. Both faced the threat of losing their homes in sales in execution for trifling debts. The litigation was instituted by the only firm of attorneys in Prince Albert, so that, even if the applicants could have afforded representation, none was available locally. No legal aid facilities were available to them. However, the intervention of an attorney, acting pro bono, enabled them to avoid losing their homes and culminated in a successful constitutional challenge to the relevant provision of the Magistrates' Courts Act 32 of 1994.

Kuppan defines legal aid as not only legal representation but also legal advice, legal education and training. ${ }^{3}$ However, the predominant need is for access to free legal representation because without the ability to resort to litigation, legal knowledge alone is not always sufficient to vindicate one's rights. When unrepresented vulnerable persons face legal proceedings, as in Jaftha, pro bono representation is often the last hope.

$1 \mathrm{~J}$ Allen 'Focusing Legal Aid on Criminal Defence Marginalizes Women's Legal Service Needs' (1995) 11 SAJHR 143, 149.

22005 (2) SA 140 (CC).

3 G Kuppan 'Legal Aid' in MP Olivier et al (eds) The Extension of Social Security Protection in South Africa: A Legal Inquiry (2001) 131, 133. 
Our constitutional 'foreparents' did not overlook this need. The Constitution guarantees the provision of legal representation at state expense in criminal matters where substantial injustice would otherwise result. ${ }^{4}$ This is a generous guarantee, which the state has attempted, in good faith, to secure. ${ }^{5}$ It goes beyond the scope of this article to consider the extent to which the state has in fact succeeded in providing criminal legal aid. It is worth noting, however, that the notion of a 'fair' criminal trial includes the provision of free legal representation where 'substantial injustice would otherwise result'.

By contrast, in civil matters, s 34 provides that:

Everyone has the right to have any dispute that can be resolved by the application of law decided in a fair public hearing before a court or, where appropriate, another independent and impartial tribunal or forum.

According to McQuoid-Mason, s 34 does not impose a duty on the state to provide legal aid in a civil suit to those who cannot afford it. ${ }^{6}$ This interpretation is supported by the wording of the section, which guarantees merely a 'fair trial', read in comparison with the express guarantee in $\mathrm{s} 35(3)(\mathrm{g})$ of legal representation for accused persons. However, 'fairness' in adversarial legal proceedings requires more than 'Diceyan' formal legal equality. ${ }^{7}$ The notion of formal or procedural legal equality is 'a passive and formal approach in which legal equality is regarded as being satisfied if individuals and institutions are treated as though they are equals, regardless of the profound inequalities within their actual relationships, ${ }^{8}$

In the context of civil litigation, this notion of procedural legal equality presupposes two things: firstly, that people with a cause of action or a legal defence are aware of their rights; and secondly, that such people are able to bring their case to court and present it competently. In the majority of cases in South Africa, these presuppositions do not hold. Social, financial, cultural as well as language barriers prevent many from asserting their rights. ${ }^{9}$ Sarkin notes that the flaw in the adversarial system is the premise that justice will be served as both parties have the ability to influence the judge equally. ${ }^{10}$

4 Section 35(3)(g).

5 The Legal Aid Board provided indigent accused with legal aid in 246231 cases in the years 2001-02 and 2002-03 taken together. See the Legal Aid Board Annual Report 2002/3, 14 Figure 7.

6 D McQuoid-Mason 'The Delivery of Civil Legal Aid Services in South Africa' (2000) 24 Fordham Int LJ S-111, S-112.

7 A Lester 'Legal Aid in a Democratic Society' in Faculty of Law, University of Natal Legal Aid in South Africa (1974) 1-17, 1.

8 Ibid.

9 Kuppan (note 3 above) 133.

$10 \mathrm{~J}$ Sarkin 'Restructuring the Legal Profession and Access to Justice: The Duty of Law Graduates and Lawyers to Provide Legal Services' (1993) 9 SAJHR 223, 226. 
Chief Justice Pius Langa expressed this simple truth: 'As far as litigation is concerned, there can be no equality [or fairness] where the combatants do not enjoy equality of arms. ${ }^{11}$ Substantive fairness can never be secured without 'equality of arms', which effectively means adequate legal advice and representation. ${ }^{12}$ If the state and legal profession fail to provide legal aid for the entire population of South Africa, the guarantee of a 'fair' public hearing rings hollow.

Traditionally, criminal legal aid has been prioritised over civil. ${ }^{13}$ This should be questioned for a number of reasons. ${ }^{14}$ First, statistical evidence indicates that the main beneficiaries of criminal legal aid are men, while mainly women seek civil legal aid. ${ }^{15}$ Relatively few women are charged with criminal offences, and their need for legal services is predominantly in the civil arena, particularly in divorce cases. ${ }^{16}$ In the South African context, in 1992-93, divorces made up 19 per cent of the Legal Aid Board's caseload, the next largest category after criminal matters. ${ }^{17}$ However, the Board now rarely provides assistance in divorce cases. Prioritising criminal legal aid over civil may amount, prima facie, to indirect discrimination on the basis of gender. However, particularly given the explicit constitutional obligation in respect of criminal legal aid in s 35, such discrimination may not be unfair in terms of s 9(3).

A second objection to prioritising criminal legal aid is that a greater proportion of the population requires civil than criminal representation. ${ }^{18}$ The traditional justification for this prioritisation is that criminal matters potentially have more serious consequences, particularly the deprivation of liberty, ${ }^{19}$ and also that there is an imbalance of resources and expertise between the prosecution and an unrepresented accused. The Canadian National Council of Welfare Report on Legal Aid counters this argument with examples of civil matters involving the removal of a child from a home in child protection cases, the involuntary commitment of psychiatric patients and the deportation of refugees. ${ }^{20}$ Another good example of civil matters with far-reaching consequences, particularly in the South African context, is found in litigation concerning socioeconomic rights, such as the constitutional rights to housing, water, food,

11 B Whittle 'Pro Bono Appealing to the Profession's Social Conscience' De Rebus (June 2002) 13.

12 See Bernstein v Bester 1996 (2) SA 751 (CC) note 154.

13 In the years 2001-02 and 2002-03 taken together, the Legal Aid Board provided legal aid in 246231 criminal matters, but only 18534 civil matters. See the Legal Aid Board Annual Report 2002/3, 14 Figure 7.

14 Canadian National Council of Welfare Report on Legal Aid (1995) 10.

15 Ibid.

16 Ibid.

17 Allen (note 1 above) 145.

18 Canadian National Council of Welfare (note 14 above) 10.

19 Allen (note 1 above) 143.

20 Note 14 above 10. 
health care services and social security. ${ }^{21}$ These examples demonstrate that a civil case can affect an individual's most fundamental interests as significantly as a criminal case.

In response to the argument that criminal proceedings involve the use of disproportionate state power to punish individuals, Budlender notes that the state's coercive powers are also at play in civil proceedings, as they are used to adjudicate and enforce claims under law made by the state. $^{22}$

In the recent case of Nkuzi Development Association v Government of South Africa, the Land Claims Court held that the Constitution does confer a right to legal representation at state expense in civil suits, at least in respect of land tenants in the circumstances of that case. ${ }^{23}$ The Court, in a judgment delivered by Moloto AJ, held that there is no logical basis for distinguishing between criminal and civil matters, as civil matters are equally complex. ${ }^{24}$ The Court held that persons who have a right to security of tenure under the Extension of Security of Tenure Act, ${ }^{25}$ whose security of tenure is threatened or infringed, have a right to legal representation or legal aid at state expense if substantial injustice would otherwise result, and if they cannot afford the cost of representation. ${ }^{26}$ The Court held that substantial injustice would result where the potential consequences of the matter are severe and the person concerned is not likely to be able to present his or her case effectively without representation. $^{27}$

The Court in Nkuzi grounded the right to representation at state expense in the property right, specifically in s 25(6) of the Constitution, which guarantees legally secure tenure 'or comparable redress'. ${ }^{28}$ The Land Claims Court seemed to assume a right to representation where 'substantial injustice' would otherwise result. The criterion of 'substantial injustice', which is contained in s 35 of the Constitution, is, however, applicable only to criminal trials. Therefore, while the outcome of $N k u z i$ is laudable, the decision does not have a sound constitutional basis, either in terms of where the court located the right to representation in the Constitution or in terms of the standard for determining when civil legal aid ought to be given.

To argue for a right to civil legal aid it is necessary to rely on the right to a fair civil hearing in s 34 , except in the case of children, to whom s 28 applies, as discussed further below. While the $N k u z i$ decision may be

21 See, for example, Government of the Republic of South Africa v Grootboom 2001 (1) SA 46 (CC) (right to housing in terms of s 26 of the Constitution).

22 G Budlender 'Access to Courts' (2004) 121 SALJ 339, 351.

232002 (2) SA 733 (LCC).

24 Ibid 737.

25 Act 62 of 1997.

26 Note 23 above.

27 Ibid order 1.3.

28 Ibid 734. 
correct in holding that there is no principled reason to distinguish between civil and criminal matters in relation to the importance of legal representation, the textual distinction in the Constitution cannot be ignored. Section 35 of the Constitution refers explicitly to legal representation as an aspect of a fair criminal trial where 'substantial injustice' would otherwise result, but s 34 makes no such guarantee in relation to a fair civil hearing. In Legal Aid Board v Msila, the court endorsed the principle, originally laid down in Legal Aid Board guidelines and adopted by the courts, that the substantial injustice test is satisfied where the applicant for legal aid is criminally charged and faces the danger of imprisonment without the option of a fine. ${ }^{29}$ This test clearly cannot apply to civil matters.

This does not mean, however, that the concepts of fairness in criminal and civil trials might not overlap. Fairness in s 34 might, therefore, include legal representation, which is specifically listed in s 35 as part of a fair criminal trial, in the latter provision triggered by the 'substantial injustice' criterion. The Constitutional Court has held that the right to a fair criminal trial is not limited to the specific rights listed in $\mathrm{s} 35 .^{30}$ Proceeding by analogy, the fact that legal representation is listed as an element of a fair criminal trial but is not expressly mentioned as an aspect of the right to a fair civil hearing does not preclude the courts from interpreting s 34 to include such a right. ${ }^{31}$ This must, however, be done on the basis of the wording of s 34 , and one cannot simply import the s 35 criterion of 'substantial injustice'.

Rather, it is necessary to consider what 'fairness' requires in the circumstances of each case. Fairness in the civil context requires consideration of factors different from those that apply in determining whether 'substantial injustice' will result in the criminal context. These factors can be gleaned from case law.

Budlender demonstrates that provisions similar to s 34 have been interpreted to include a right to representation in some civil suits in international and foreign law. ${ }^{32}$ South African courts interpreting the Constitution are obliged to consider international law and permitted to consider foreign law, in terms of s 39 of the Constitution. Under international law, criminal legal aid is prioritised, with the major international instruments mirroring the Constitution in guaranteeing free legal representation in criminal cases and merely a procedurally 'fair' trial in civil matters. ${ }^{33}$ Nevertheless, the European Court of Human

33 See, for example, art 14(1) and art 14(3)(d) International Covenant on Civil and Political Rights (1966); art 6(1) and art 6(3) European Convention on Human Rights (1950); art 7 and art 8(2)(e) American Convention on Human Rights (1969); art 26 African Charter on Human and People's Rights (1981). 
Rights has interpreted art 6 of the European Convention on Human Rights to include a right to representation in some civil cases. ${ }^{34}$ Article 6(1) refers to a 'fair and public hearing', while s 34 of the Constitution guarantees a 'fair public hearing'.

In Airey $v$ Ireland, the European Court held that the Irish government's failure to provide Mrs Airey with free representation for the purpose of securing a judicial separation violated her right of access to court in Art 6(1). ${ }^{35}$ Research presented as evidence could not provide a single instance in which a decree of judicial separation had been obtained in Ireland without legal representation. ${ }^{36}$ The effect of Airey is that a fair civil hearing may, in certain circumstances, require the provision of legal representation at state expense. Article 6 of the European Convention is almost identical to $\mathrm{s} 34$ of the Constitution. This provides strong grounds for interpreting s 34 to impose a similar duty on government in circumstances where a litigant is unlikely to be able to obtain relief without representation. However, Airey held that Art 6(1) does not guarantee a right to free civil legal aid, but merely obliges state parties to take steps to ensure the progressive realisation of such a right. ${ }^{37}$

The Canadian Supreme Court confronted the question of a right to free representation in civil suits in the context of $\mathrm{s} 7$ of the Canadian Charter of Rights and Freedoms in the case of $G(J) .{ }^{38}$ Section 7 reads: 'Everyone has the right to life, liberty and security of the person and the right not to be deprived thereof except in accordance with the principles of fundamental justice.' 39

The Court held that the combination of stigmatisation, loss of privacy and disruption of family life that might result from a custody suit are sufficient to constitute a restriction of security of the person. ${ }^{40}$ In deciding whether 'fundamental justice' necessitated the provision of legal representation in a particular case, the Court referred to 'the best interests of the child' as the paramount consideration. ${ }^{41}$ Provided these are not compromised, a court should then consider the interests at stake, the complexity of proceedings and the capacities of the parent. ${ }^{42}$ In the circumstances of the case, the Supreme Court held that the government was under an obligation to provide the appellant with state-funded counsel. ${ }^{43}$ It is worth noting that s 7 of the Canadian Charter, dealing

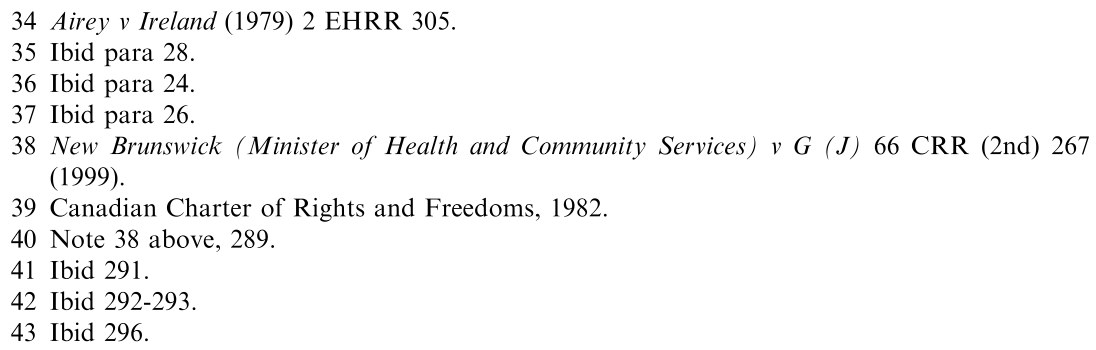


with threats to 'life, liberty and security of the person', is significantly narrower than s 34, which encompasses all civil matters.

The position under the South African Constitution is slightly different, because s 28 deals specifically with legal representation in matters affecting children. Under the South African Constitution, the Canadian case of $G(J)$ might have been considered an appropriate case for the appointment of a legal representative to act for the child concerned. In the case of children's rights in civil suits, which are distinct from the right of all persons under s 34, s 28(1)(h) guarantees a child's right to 'have a legal practitioner assigned to the child by the state, and at state expense, in civil proceedings affecting the child, if substantial injustice would otherwise result'.

Section 28, therefore, expressly guarantees legal representation for children. ${ }^{44}$ The right appears not to be limited by the state's resource constraints, but is confined to cases where 'substantial injustice' would result if representation at state expense were not provided. The provision is applicable not only to matters in which a child is a party to a civil suit, but in any matter 'affecting' the child, which would include adoption, custody, maintenance and possibly even divorce matters. In such matters, the representative would be 'assigned to the child', and directly represent him or her. The role of such a s 28 legal representative was usefully discussed in Soller NO v G, ${ }^{45}$ where Satchwell J explained:

The legal practitioner stands squarely in the corner of the child and has the task of presenting and arguing the wishes and desires of that child... The legal practitioner does not only represent the perspective of the child concerned. The legal practitioner should also provide adult insight into those wishes and desires which have been confided and entrusted to him or her as well as apply legal knowledge and expertise to the child's perspective. $^{46}$

In Christian Education $S A v$ Minister of Education, Liebenberg $\mathbf{J}$ held that s 28 makes it clear that the state is responsible for the expenses of a legal representative appointed in terms of $\mathrm{s} 28(1)(\mathrm{h}) .{ }^{47}$ However, this does not cater for the interests of parents, and their claim to state-funded legal aid would fall under s 34 , as s 28 is concerned with the child's right to legal representation.

To sum up, the state's constitutional obligations to provide legal aid are differentiated in respect of criminal and civil matters, and special provision is made for matters affecting children. The Constitution contains an express guarantee of free legal representation in all criminal matters and all civil matters affecting children "where substantial injustice

44 For a more comprehensive discussion of the child's right to be heard, see J Gallinetti 'Article 12 of the UN Convention on the Rights of the Child and Implementing the Child's Right to be Heard' (unpublished LLM Minor Dissertation, University of Cape Town 2001).

452003 (5) SA $430(\mathrm{~W})$.

46 Ibid para 27.

471999 (4) SA 1092 (SE), 1097. 
would otherwise result'. This creates a positive right to legal representation, which is, in principle, justiciable.

In other civil matters, s 34 makes no such guarantee. A similarly worded guarantee of a 'fair hearing' in Art 6 of the European Convention on Human Rights was interpreted in Airey to require free legal representation in certain circumstances. However, a major difference between Art 6 and s 34 is that the former applies to both civil and criminal matters. Therefore, the fact that the Constitution expressly guarantees free legal representation only in criminal matters and matters affecting children must carry some weight, although legal representation must still form part of the concept of 'fairness' in s 34 . The criterion of 'substantial injustice' cannot simply be imported into the interpretation of s 34. Rather, factors such as those discussed in the cases of Nkuzi, Airey and $G(J)$ must be used to determine when a failure by the state to provide civil legal aid will render a hearing unfair in terms of s 34. These include the interests of the litigant that are at stake, the complexity of the proceedings and the capacity of the litigant to represent herself.

Where evidence can be adduced to show that a particular type of litigation is unlikely to succeed without representation, as in Airey, the lack of free legal representation is more likely to render a civil hearing unfair. $^{48}$ This was successfully done in the Nkuzi case, where the Legal Resources Centre conducted research into evictions of farm-dwellers. ${ }^{49}$ However, even where such research can be presented as evidence, it is not clear that the courts will interpret s 34 to confer a right to civil legal aid on demand. At least, courts will also have to consider the capacity of the litigant to represent him or herself, and the complexity and potential consequences of the litigation. These factors would have to be weighed together to determine whether a failure to provide representation would render a civil trial unfair. This would not be the case in all civil matters and for all civil litigants. Relatively well-educated civil litigants engaging in fairly straightforward civil litigation might not be entitled to free representation.

On this analysis of $\mathrm{s} 34$, the state is under a duty to implement a comprehensive programme for the provision of free civil legal aid to those who cannot afford it where, in the circumstances of each case, the failure to do so would render the civil trial unfair. However, resource constraints prevent the state from doing so alone. Given that the Legal Aid Act 22 of 1969 is a 'law of general application' in terms of the limitations clause in s 36 of the Constitution, the state's obligations to provide legal aid in civil matters are difficult to determine. ${ }^{50}$ A limitations analysis goes beyond the scope of this article, but a few observations can be made. As a starting

48 Budlender (note 22 above) 340-341.

49 Ibid.

50 See the discussion in Budlender (note 22 above) 347-356. 
point, the state's obligations are unlikely to cover legal aid in all civil litigation, whether the rights of civil litigants are limited by narrowly construing the scope of the right (fair) in s 34 , or by means of a s 36 limitation. I agree with Ellmann that costs and resource constraints are likely to play a greater role in limiting the state's obligations in the context of civil legal aid under s 34 than in respect of criminal legal aid under $\mathrm{s} 35 .^{51}$ Budlender, noting certain conceptual difficulties with allowing resource constraints to justify a limitation under s 36 , suggests that this factor should be considered in deciding on remedy. ${ }^{52}$

Whatever the theoretical route taken, sweeping judicial intervention to overhaul the entire state legal aid system is highly unlikely. ${ }^{53}$ However, an order declaring a breach of the state's obligations, but suspended to allow time for government to develop a programmatic response to the lacuna in respect of civil legal aid might be the most appropriate judicial response. $^{54}$ This would simply act to prompt a policy response from the state.

One possible policy approach, with the advantage of mitigating the expense to the state of providing free legal aid, is to implement a programme of compulsory pro bono work for practising lawyers, law students or graduates. Even if the state is considered to bear the primary obligation to deliver civil legal aid under s 34, the legal profession arguably shares this responsibility, as the custodian of the system of justice. ${ }^{55}$ Arguably, therefore, the state might be entitled to look to the organised profession to assist in discharging its constitutional obligations, and to go beyond the state's obligations to provide civil legal aid in cases where the state is not bound to do so. As will be discussed below, the ideal situation is for representative bodies of the legal profession to undertake a self-imposed compulsory system as a matter of professional constitutional obligation. However, were they unwilling to do so, the state might impose such obligations by virtue of its power to regulate professions.

To understand the debate around compulsory pro bono programmes, it is necessary to contextualise it against the background of the different programmes adopted in the past in South Africa for the provision of civil legal aid. Lessons can be learnt from these experiences, which are important in considering the pro bono option.

51 S Ellmann 'Weighing and Implementing the Right to Counsel' (2004) 121 SALJ 318, 328-9.

52 Budlender (note 22 above) 353.

53 Ellmann (note 51 above) 337.

54 Budlender (note 22 above) 357-8.

55 B Cardin and R Rhudy 'Symposium: Expanding Pro Bono Legal Assistance in Civil Cases to Maryland's Poor' (1990) 49 Maryland LR 1, 13. 


\section{HISTORICAL BACKGROUND}

The meaning of 'access to justice' in the South African context has changed with time. Under apartheid, it meant 'an attempt to expand the space for activists to work toward the dismantling of the apartheid state through protest, mass action and through the courts'. ${ }^{56}$ In the fledgling constitutional democracy today, 'access to justice' must mean shaping the legal institutional framework to better serve the whole population, and make good on constitutional promises of genuine social and economic advancement within the new political climate. The institutions responsible for the provision of legal aid can be divided into state-sponsored programmes and non-governmental initiatives.

\section{(a) State-sponsored programmes}

The state first put in place a programme for the provision of legal aid to indigent persons in 1962. ${ }^{57}$ The scheme emerged from negotiations between the Department of Justice and the organised legal profession. Attorneys and advocates agreed to provide free legal services to any person referred to them by a local legal aid committee to be set up at each magistrates' court. As McQuoid-Mason notes, the system failed for three main reasons: first, lack of publicity; secondly, the work went unpaid, resulting in a lack of motivation and poor standards; and lastly, excessive bureaucracy or 'red tape'. 58

In 1969, the Legal Aid Board was established in terms of the Legal Aid Act 22 of 1969. It remains the largest provider of legal aid and is tasked with discharging the state's obligations to provide legal assistance. In terms of the Act, the Board must 'render or make available legal aid to indigent persons'. ${ }^{59}$ It provides assistance in criminal and civil matters, subject to certain exclusions and a financial 'means test'. Until recently, the Board used state-compensated private attorneys and advocates, the so-called 'judicare' model. ${ }^{60}$

Under this system, an indigent person could apply to the Board. If approved, the applicant was referred to a private practitioner of his or her choice. The practitioner was paid by the Board. There were two main problems with the system. First, it was relatively expensive: the average cost of a judicare case in 1998 was R1 $423 .{ }^{61}$ This is considerably more expensive than a salaried lawyer scheme. ${ }^{62}$ Secondly, the Board lacked

56 D Bengtsson 'Justice for All? Law Clinics in South Africa' (unpublished LLM thesis, University of Natal 2002, 2).

57 McQuoid-Mason (note 6 above) S-117.

58 Ibid.

59 Section 3 of the Legal Aid Board Act.

60 McQuoid-Mason (note 6 above) S-117.

61 Legal Aid Board Legotla: Overview of the Board and its Activities 8 (Nov 1998), Unpublished report of the Legal Aid Board, cited in D McQuoid-Mason (note 6 above) S-121.

62 McQuoid-Mason (note 6 above) S-121. 
the administrative infrastructure to run the scheme, so that accounts often took years to settle and there was little 'quality control' in respect of services dispensed by private practitioners. ${ }^{63}$

In 1995, a pilot project was established in co-operation with Lawyers for Human Rights. ${ }^{64}$ With the agreement of small-town law firms, the Board assisted with the payment of salaries of candidate attorneys, ${ }^{65}$ who were to handle at least ten new cases a month at no cost on behalf of the Board. ${ }^{66}$ This initiative is very cost-effective, but is used mostly in criminal matters. ${ }^{67}$ It appears ideal for rural areas, where large justice centres would not be cost-effective, but this pilot project has unfortunately been discontinued.

In 1998, the Board, near bankrupt and with a huge backlog of unpaid accounts from private practitioners, adopted a new model. Justice centres were envisaged as 'one-stop legal aid shops', to provide comprehensive legal services through salaried candidate attorneys, attorneys, advocates, paralegals and administrative staff. ${ }^{68}$ The services provided include an initial consultation or screening process, legal advice, non-litigious dispute resolution methods such as arbitration and mediation, as well as legal representation. The Board began with the establishment of pilot urban and rural centres and aimed to establish 57 urban and 14 rural centres by the end of $2003 .{ }^{69}$ At the end of 2003, 59 justice centres and 28 satellite offices were functioning. ${ }^{70}$

Justice centres have three main advantages. First, the average cost of a case is greatly reduced. ${ }^{71}$ Secondly, these should provide direct access to comprehensive legal assistance. Thirdly, the twin risks of over-charging and under-performing that existed under the judicare model are potentially eliminated. Although concerns about the quality of service will remain, it is easier for the Board to evaluate the performance of justice centres and their staff than that of private practitioners handling judicare matters. ${ }^{72}$ The Board has decided to move away from the judicare model to the justice centre model, and, in 2003/4, managed to reduce judicare referrals to 16 per cent of its caseload, a figure it hopes to reduce further each year. ${ }^{73}$

\footnotetext{
63 Ibid S-121.

64 Ibid S-122. An earlier pilot project was the Johannesburg public defender office, which was the precursor of the justice centres.

65 Ibid.

66 Ibid.

67 Ibid.

68 Ibid S-125 to S-126.

69 Legal Aid Board Business Plan Covering the Period 2000 to 2003 (1999) 20.

70 Legal Aid Board (note 5 above), 14 Figure 4.

71 The average cost of a judicare case was R1 867, while the average cost of a justice centre case is R803. Ibid 14 Figure 5.

72 The Legal Aid Board has already put in place monitoring and evaluation mechanisms, including reporting and auditing requirements. See the Legal Aid Board (note 5 above) 12.

73 Ibid 19 Table 5 .
} 
The Board has also entered into co-operative projects with law clinics at universities. This programme began in 1995 with six universities. ${ }^{74}$ There are currently twelve co-operation agreements between university law clinics and the Legal Aid Board, creating formal links between these clinics and specific justice centres. ${ }^{75}$ Six university clinics have entered into such agreements, namely the universities of the North West (formerly Potchefstroom), ${ }^{76}$ Venda, Pretoria, Witwatersrand, Free State and Nelson Mandela Metropolitan University (formerly Port Elizabeth). These Legal Aid Board clinics are separate, at least in theory, from the independent university legal aid clinics, which have now been set up at all 21 law schools in the country. ${ }^{77}$ In practice, the clinics at the six universities mentioned above simply have internal divisions, some funded by the Board and some independently funded. ${ }^{78}$ The Board funds attorneys and candidate attorneys who render legal services to indigent persons in criminal and civil matters. ${ }^{79}$

To receive legal assistance through any of the legal service providers funded by the Legal Aid Board, an applicant must meet certain criteria. In terms of the Legal Aid Act, legal aid is only rendered to 'indigent' persons. ${ }^{80}$ The term is not defined in the Act, but has been defined, although not in the context of the Act, in the case of Smith v Mutual \& Federal Insurance Co Ltd, distinguishing 'indigent' and 'poor'. ${ }^{81}$ The judge stated that 'to be indigent means to be in extreme need or want whereas to be poor means having few things or nothing, ${ }^{82}$

On the basis of the term 'indigent', the Board has laid down a financial means test, which is revised from time to time, but in which the threshold remains low enough to exclude a large group. At present, the means test provides that to qualify one must earn less than R1 200 a month if single or less than R2 000 for a couple with a child. ${ }^{83}$ To this one can add R180 for each child. Perhaps 50 per cent of our population would qualify. ${ }^{84}$ However, this excludes a large proportion of the population people who

74 D McQuoid-Mason 'Legal Representation and the Courts' in Ronald Louw (ed) SA Human Rights Yearbook (1995) 148, 155.

75 I am grateful to Mr Schalk Meyer, President of the Association of University Legal Aid Institutions (AULAI) for supplying me with this information, by email on 2 December 2003.

76 There are seven agreements between North West University and different justice centres in Mpumalanga, Vaal Triangle and the North West.

77 Kuppan (note 3 above) 140.

78 McQuoid-Mason (note 74 above) 155.

79 Kuppan (note 3 above) 140

80 See the long title of the Legal Aid Act.

811998 (4) SA 626 (C), 632.

82 Ibid.

83 See the Legal Aid Board website at < http://www.legal-aid.co.za/services/qualifications.htm $>$.

84 Statistics show that in 1999 more than 50 per cent of South African households had a total income of less than R1 400 per month. This figure comes from the All Media Products Survey published by the South African Advertising Research Foundation. See the South African Institute of Race Relations Survey 2000/2001 369 cited in C O'Regan 'Producing Competent Graduates: The Primary Social Responsibility of Law Schools' (2001) 118 SALJ 242, 244. 
earn above this threshold but are still unable to afford private representation, perhaps as many as 15 per cent or more of the population. ${ }^{85}$ As noted by Kuppan, this strict threshold limits the provision of legal aid to those persons in extreme need or want for the basic necessities of life. ${ }^{86}$ It excludes the broad group of the working poor and middle class.

The provision of legal aid by the Board is also restricted according to the type of matter for which assistance is sought. Exclusions include defamation matters, 'undeserving' divorce cases, most maintenance matters and family violence. ${ }^{87}$ The Board largely prioritises criminal matters over civil legal aid: 88 per cent of the latest Board budget was spent on criminal legal aid. ${ }^{88}$

Another problem is physical access to state legal aid resources in rural areas, which remains very limited. The few justice centres established in rural areas concentrate on criminal matters, in line with the Board's general policy of prioritising criminal legal aid. ${ }^{89}$ Kuppan notes that these exclusions and limitations create a 'marginalised group' consisting of the rural populace and the urban working poor and middle class. ${ }^{90}$ The former are excluded mainly because of a factual lack of services in rural areas; the latter are shut out by the definition of 'indigent'.

\section{(b) Non-governmental initiatives}

Non-governmental initiatives take two main forms: independent university law clinics and non-governmental organisations (NGOs).

Independent law clinics have been set up at all of South Africa's twenty-one law schools. Attorneys and candidate attorneys supervise law students who render legal assistance to indigent and poor people. These clinics have two main objects: rendering community service and providing practical legal training for law students. ${ }^{91}$ The means tests of these clinics are less strict than that of the Board, allowing a greater proportion of the working poor to gain access to their services. ${ }^{92}$ The university law clinics are represented by the Association of Independent University Legal Aid Clinics (AULAI). ${ }^{93}$ Their accessibility is increased

85 See the 'General Household Survey 2002' conducted by Statistics South Africa. In the sample group, approximately 13 per cent of households had a monthly expenditure of between R 1200 and R2 500, while for about 7 per cent this amount was between R2 500 and R5 000. This survey can be viewed on the Stats SA website: <www.statssa.gov.za >

86 Kuppan (note 3 above) 136.

87 Legal Aid Guide 2001.

88 Legal Aid Board (note 5 above) 20 Table 7.

89 Kuppan (note 3 above) 150.

90 Ibid 151.

91 See, for example, the Constitution of the University of Cape Town Legal Aid Clinic (unpublished).

92 Kuppan (note 3 above) 141.

93 McQuoid-Mason (note 6 above) S-129. 
by the fact that some operate outside normal working hours and work within communities. ${ }^{94}$ However, their efficacy is limited by resource constraints that prevent them from giving an across-the-board guarantee of civil legal aid. ${ }^{95}$

In addition, several NGOs offer free legal assistance in civil matters. Most, however, are pilot projects, specialise in a narrow area of law or target particular sectors of the population. An example of a targeted pilot project is the Community Law and Rural Development Centre, Durban, which provides legal education and advice to about a million rural people living in KwaZulu-Natal and the Eastern Cape. ${ }^{96}$ Examples of specialist organisations are the Legal Resources Centre (LRC), Lawyers for Human Rights (LHR) and the Women's Legal Centre (WLC). ${ }^{97}$ The LRC is South Africa's largest public interest law firm and engages in strategic impact litigation. ${ }^{98}$ LHR, similarly, has targeted and still targets human rights issues for litigation, ${ }^{99}$ such as the death penalty case ${ }^{100}$ and, more recently, a high court challenge to the Immigration Act. ${ }^{101}$ The WLC aims 'to advance women's rights by conducting constitutional litigation and advocacy on gender issues' ${ }^{102}$ An exception to this targeted approach is the Black Sash, which still provides wide-ranging poverty law advice and assistance through advice offices located around the country. ${ }^{103}$ However, it too has limited resources.

Although these NGOs play a valuable role, that role does not include a broad guarantee of legal assistance for the vast marginalised group not covered by the Legal Aid Board. Rather, they predominantly target specific areas of the law as ripe for strategic impact litigation, and concentrate on those cases.

\section{Reform: Serving the 'Marginalised GrouP'}

Major reform is necessary if the civil legal aid system is adequately to serve the group that is currently excluded. I will consider two proposals. Both involve sectors of the mainstream legal community rendering services, and both involve an element of compulsory participation. I argue that an extensive programme is required to guarantee civil legal aid

\footnotetext{
94 Ibid S-130-131.

95 Ibid S-132.

96 Ibid S-134.

97 Kuppan (note 3 above) 143.

98 Ibid.

99 See the Lawyers for Human Rights website: <www.lhr.org.za > .

$100 S v$ Makwanyane 1995 (3) SA 391 (CC). Lawyers for Human Rights was admitted as an amicus curiae, while the Legal Resources Centre acted for the applicant.

101 Lawyers for Human Rights $v$ Minister of Home Affairs (TPD 21 April 2003, unreported).

102 See the Women's Legal Centre website: <www.wlce.co.za $>$.

103 See the Black Sash website: <www.blacksash.org.za $>$.
} 
to the marginalised group of rural people and the working poor and lower middle class. Three simple statistics are relevant:

(i) South Africa has a total population of about 45 million, the majority of whom are impoverished, with a household income that does not allow them to secure private legal representation; ${ }^{104}$

(ii) South Africa has approximately 14000 practising attorneys; ${ }^{105}$ and

(iii) South Africa has twenty-one law schools, which produce an average of 2500 graduates each year. ${ }^{106}$

On the basis of the above statistics, it is my view that the most effective reform for the provision of civil legal aid would be a two-pronged programme comprising compulsory pro bono work by practising attorneys, and compulsory community service by law students and/or graduates.

\section{(a) Compulsory pro bono work by attorneys}

\section{(i) The Cape Law Society: Mandatory pro bono}

At its 2002 Annual General Meeting (AGM), the Law Society of the Cape of Good Hope passed a motion that will make it mandatory for all practising attorneys in the Western, Eastern and Northern Cape to do 24 hours of pro bono work each year. ${ }^{107}$ This came after the Cape Law Society had approved mandatory pro bono in principle at their AGM of $2001{ }^{108}$ The Cape Law Society will be moving to amend its practice rules to cater for this new policy. ${ }^{109}$

The Cape has led the way as the first provincial law society to pass such a resolution. The services will be rendered in a number of areas of civil and criminal law, in terms of a list of such services that is intended to form part of the new rule governing pro bono work. ${ }^{110}$ These include various areas of general practice, as well as Small Claims Court work. The attorneys will render the services through pre-existing 'recognised structures' such as university clinics, NGOs and community advice offices and through the High Court when the Registrar issues in forma pauperis instructions. ${ }^{111}$ The Cape Law Society will enter into a "joint

104 Stats SA National Population Census 2001: the final results reflected a population of 44,8 million See the Stats SA website: <http://www.statssa.gov.za/Specialprojects/Census2001/ Census2001.htm $>$.

105 O'Regan (note 87 above) 244.

106 Ibid.

107 'Cape Attorneys Opt for Mandatory Pro Bono Work' De Rebus (December 2002).

108 Ibid.

109 A draft rule 21 to be inserted into the Cape Law Society's rules has been circulated among attorneys for comment.

110 Draft rule 21.4, Cape Law Society Rules.

111 Draft rule 21.1, Cape Law Society Rules. 
venture agreement' with these legal service providers and courts to facilitate the rendering of pro bono services. ${ }^{112}$ Each attorney will have to submit a proposed 'area of professional work for recognition as pro bono services'. ${ }^{113}$ An example of the type of services that will be rendered is the supervision of students at 'satellite' university legal aid clinics.

\section{(ii) Compulsory pro bono nationally?}

The Cape Law Society is thus far the only provincial body to have made mandatory the rendering of pro bono services. The question was discussed at the 2002 AGMs of the Law Society of Northern Province and the Free State Law Society, but no position was taken. ${ }^{114}$ At the Free State AGM there was some opposition to the idea of pro bono work being made mandatory, as it was argued that many attorneys already provide free assistance voluntarily. ${ }^{115}$ The Law Society of South Africa (LSSA) has expressed the view that pro bono work should be voluntary. ${ }^{116}$ The then executive director of the LSSA, André van Vuuren, stated at a pro bono conference in May 2002 that the LSSA was 'firmly and irrevocably committed to the concept of pro bono' ${ }^{117} \mathrm{He}$ went on, however, to emphasise the difficulties with such a programme, particularly that small firms struggle to divert scarce resources to pro bono work. ${ }^{118} \mathrm{He}$ suggested tax reductions or financial incentives to make pro bono work more attractive. ${ }^{119}$

The debate over the introduction of pro bono work for attorneys seems to be approaching a climax. The programme being implemented by the Cape Law Society is leading the way.

It should be noted that there is also momentum behind pro bono proposals at the General Council of the Bar and its constituent bar councils. Obviously, a pro bono programme adopted by advocates would complement whatever programme the attorneys' profession settles on.

\section{(iii) Advantages of compulsory pro bono for attorneys}

The most important advantage of making pro bono for attorneys compulsory is simply that such a programme will increase the resources available to those who cannot afford private legal assistance. Using the relatively modest Cape model of 24 hours per attorney per year, and

112 Draft Joint Venture Agreement, submitted with the Motion by the Council of the Cape Law Society at the 2002 AGM.

113 Draft rule 21.3, Cape Law Society Rules.

114 See 'Cape Attorneys Opt for Mandatory Pro Bono Work' (note 107 above).

115 Ibid.

116 Ibid.

117 Whittle (note 11 above) 14.

118 Ibid.

119 Ibid. 
given that there are almost 14000 practising attorneys in South Africa, a national programme would generate approximately 336000 hours of pro bono time per year. This would go a long way to improving access to civil justice in particular, because most of this work would involve civil matters. This programmatic approach cannot properly be undertaken other than compulsorily, as voluntarism would contribute neither the personnel nor the potential to administer systematically that a mandatory policy would ensure.

Besides administrative costs that would be borne by the Law Society, the defining feature of pro bono work is that it is free. This is even more significant given the fact that the Legal Aid Board is only just beginning to extricate itself from the financial turmoil in which it found itself prior to the decision to move away from the 'judicare' system, which left the Board with huge debts and an enormous backlog of unpaid claims. ${ }^{120}$ In 2002, the Board reported its first saving in ten years in its financial results. $^{121}$ A pro bono programme avoids the risk of the Board again running up huge debts owed to practising lawyers.

Another advantage is the prospect of creating an ethos of public service. ${ }^{122}$ A pro bono programme should have the result that attorneys will begin to view the facilitation of access to legal services by the poor as a responsibility shared by the state and the legal profession. This would also improve the public image of the profession.

The programme would also give recognition to pro bono work. Willem de Klerk, a Johannesburg attorney who is the former head of the University of Witwatersrand's Clinic, suggests that recognition can be provided through media coverage and awards. ${ }^{123}$ Even without such additional steps, simply institutionalising pro bono work will afford a measure of recognition that has not been given to the many attorneys who have been giving 'unofficial' free services to indigent clients. ${ }^{124}$

Foreign studies have indicated that the highest earning private practitioners reported the lowest level of job satisfaction, while law professors and public interest lawyers derived the most 'psychic income' from their work. ${ }^{125}$ This suggests, quite simply, that lawyers involved in pro bono work are likely to be happier in their work than the "corporate firm population'. ${ }^{126}$ Edwards notes that these statistics also suggest a link between low 'psychic income' (job satisfaction) and stress-related

120 See the News 24 website: <www.news24.com/News24/South_Africa/Gauteng/0,1113,2-7829 1240926,00.html >.

121 Ibid.

122 McQuoid-Mason (note 6 above) S-116-117.

123 Whittle (note 11 above) 14.

124 There is no statistical evidence of unofficial free legal aid, but it is often referred to, for example in Whittle ibid 15.

125 K Edwards 'Found! The Lost Lawyer' (2001) 1 Fordham LR 37, 55.

126 Ibid. 
diseases. ${ }^{127}$ Of course, it may well be that these differences in 'psychic income' and stress-related diseases have more to do with the reasons for choosing to enter private practice or public interest work and the nature of the work. Nevertheless, in a grossly unequal society like South Africa, professionals who are required to assist in alleviating the plight of the poor may draw a sense of patriotic contribution from their pro bono work.

The programme might also assist in bridging the divide between the attorneys' profession and NGOs. By requiring attorneys to render free services through joint venture agreements between the (Cape) Law Society and specific NGOs, the programme will establish formal links between the organised legal profession and non-state actors. These links may help to imbue the attorneys' profession with the sense of public service that is characteristic of many of these NGOs.

\section{(iv) Objections to compulsory pro bono for attorneys}

The potential problems with a policy of compulsory pro bono will be considered as general objections, using the Cape model as an example. Afterwards, the Cape model itself will be evaluated, in the context of South African conditions and on the basis of its specific requirements.

The commonly cited quality-control concern is that, without sufficient supervision and regulation, the services rendered could degenerate into 'second-rate justice'. ${ }^{128}$ Given that indigent persons will often not be able to demand better service, this is a real concern. Cousins notes that an important means of ensuring quality service is regular and extensive evaluation of a country's legal aid scheme. ${ }^{129}$ In France, a special consultative board has been set up specifically for this purpose. ${ }^{130}$

Another concern is the possible unintended effect of setting a ceiling rather than a floor. The Cape Law Society's model will require only two hours a month of pro bono work. This is a fairly modest demand, although not insignificant. The concern is, however, that lawyers will feel that their moral obligation to assist indigent persons goes no further than those two hours a month. In my view, the two hours a month should rather be seen as a minimum. Two hours a month is almost certainly less than the time required to litigate one civil case. If that is true, what is the point of setting such an amount of time as mandatory?

It has also been contended that, for small firms and attorneys struggling to establish themselves, unremunerated work can be unaffordable. However, this point is contentious. In the survey on community

127 Ibid.

128 Whittle (note 11 above) 14.

129 M Cousins 'Civil Legal Aid in France, Ireland, the Netherlands and the United Kingdom: A Comparative Study' (1993) 12 Civil Justice Quarterly 154, 160. 130 Ibid. 
service conducted by the Cape Law Society, two completely divergent points of view were reflected in responses. While one response read 'Young practitioners have less time as they are building practices', another attorney said 'Senior practitioners have bigger practices and less time, thus younger practitioners must do more. ${ }^{131}$

These comments are open to two interpretations: either both junior and senior attorneys are generally short of time, or the comments simply attempt to rationalise an unstated antipathy towards community service. However, if all that is required is two hours a month, time pressure cannot be a serious concern. The reluctance of attorneys to take pro bono matters that is if pro bono is subjectively onerous even if they can afford the time, is nevertheless a real concern. ${ }^{132}$ This also relates to the 'quality control' problem discussed above.

The two comments by senior and junior attorneys above also indicate the difficulty of trying to accommodate the incommensurable differences between different types of practice, large and small firms and attorneys of varying experience. A uniform requirement of pro bono work seems, therefore, the simplest and least controversial way to avoid such minefields, especially if the required amount of service is not very demanding.

A related objection to compulsory pro bono is the argument that the burden of providing legal services should be carried by the whole society, not the legal profession alone. ${ }^{133}$ On this view, legal aid is a government responsibility, to be facilitated by taxation. However, in contrast to other occupations, the practice of law carries with it an element of civil responsibility, which means that the legal profession shares the responsibility for ensuring that the law serves all persons. ${ }^{134}$

Another criticism relates to inefficient use of human resources. It is argued that it is less than optimal to require a leading contract lawyer to assist indigent divorce plaintiffs the contract lawyer's vast expertise will be entirely wasted. However, as an argument against mandatory pro bono work, this must fail for two reasons. First, attorneys may be given a degree of choice in selecting the area of law in which to render pro bono services and the contract expert can then assist with contractual disputes. ${ }^{135}$ Secondly, the argument supports maintaining the status quo in terms of which only the wealthy have access to civil justice. Therefore, the moral argument based on equality and a substantive

131 Unpublished Community Service Questionnaire compiled by the Criminal Law, Legal Aid and Community Service Sub-committee of the Cape Law Society from 28 February to 15 May 2002, para 4.

132 McQuoid-Mason (note 6 above) S-117.

133 Cardin and Rhudy (note 55 above) 12.

134 Ibid.

135 This choice is specifically provided for in the Cape Law Society's Draft rule 21 of the Cape Law Society Rules, which provides a list of possible areas of pro bono service. 
understanding of 'fairness' for making pro bono work compulsory outweighs any potential utilitarian inefficiency.

A second aspect of the inefficiency concern is whether a firm is allowed to assign a single attorney or candidate attorney to perform all its hours of community service. At present, this appears impermissible, as the Draft Joint Venture Agreement produced by the Cape Law Society must be entered into by each individual attorney and the organisation through which he/she intends to render service. ${ }^{136}$ There has been a similar proposal that practitioners be permitted to 'subcontract' community service to a candidate attorney. ${ }^{137}$ Many large firms already have dedicated attorneys and candidate attorneys who take on pro bono matters. ${ }^{138}$ While there may be utilitarian advantages to such an approach, the Cape model currently requires each individual attorney to render community service personally.

In general, a programme of compulsory pro bono work is a defensible and viable policy. However, some details of the Cape model warrant particular attention and criticism.

\section{(v) Conclusions: is the Cape model ideal?}

While the Cape Law Society has led the way in making pro bono work mandatory for its members, first is not necessarily best. While the Cape attorneys should be praised for taking this first step, their model is not immune from criticism.

First, the model seems to provide largely for what one might describe as 'indirect' pro bono, that is, for supervisory and advisory services at university clinics, community advice offices and NGOs. While this type of work must not be undervalued, it is likely that many attorneys will opt for this avenue to fulfil their pro bono obligations. The Draft Joint Venture Agreement produced by the Cape Law Society centres on the provision of advice, which is not the primary need of university law clinics. ${ }^{139}$ There is therefore unlikely to be any increase in availability of 'direct' legal services: legal representation and litigation. An increase in such services could be achieved by requiring attorneys to take unpaid matters on referral from the Legal Aid Board's justice centres and the courts. However, this will require additional administrative machinery and planning.

136 Draft Joint Venture Agreement, submitted with the Motion by the Council of the Cape Law Society at the 2002 AGM.

137 See, for example, the unpublished Community Service Questionnaire (note 131 above) numbered para 4.

138 'South Africa Pro Bono System in Public Interest' Business Day 12 September 2003. An example is the firm Bowman Gilfillan Inc, which has a pro bono committee to manage its pro bono work.

139 Letter to the Directors of University Law Clinics from W De Klerk, Secretary of the Association of Universiy Legal Aid Institutions dated 2 June 2003 on the subject of 'CLS Pro Bono Scheme', para 7. 
Secondly, the two hours a month ( 24 hours a year) is fairly modest. A cynic might wonder whether the Cape body wisely opted for this mild self-imposed pro bono programme in anticipation of a harsher one being forced upon attorneys by the government. ${ }^{140}$ The Advisory Council of the Maryland Legal Services Corporation estimated that the average pro bono case required approximately ten hours of legal work. ${ }^{141}$ Nevertheless, two hours a month is probably not sufficient time to take one motor vehicle accident case to fruition within a year. Perhaps it would be more appropriate to double the Cape's requirement to require 48 hours per year and 4 hours per month. ${ }^{142}$ Indeed, in a survey of Cape attorneys on the subject of community service, 52,5 per cent said that they would be prepared to render 48 hours of community service per year, 12,5 per cent were willing to render more than this amount, while 34,5 per cent suggested less than 48 hours per year. ${ }^{143}$

Thirdly, the Cape draft rule 21 exempts attorneys with 40 or more years of experience or who are over 60 years old from the programme. There seems no rational reason to exempt what are essentially the upper echelons of the profession from pro bono duties, and no reason was given in the resolution. These attorneys, who are presumably still sufficiently proficient to work for commercial firms, are a valuable resource of experienced 'personpower'.

Finally, the Cape Law Society scheme has not put in place mechanisms to ensure quality control. In my view, an independent body should be set up and charged with the task of evaluating pro bono services rendered in terms of the scheme, including investigating complaints received. In addition, effective sanctions need to be put in place to ensure compliance with expected standards of professional service. The Cape Law Society's existing disciplinary procedures may, however, be sufficient to deal with situations of inadequate service.

It is therefore argued that in some respects the Cape model is not ideal and some fine-tuning may prove necessary if the policy is nationalised or other provinces follow suit. One of the major redeeming features of the Cape programme is that, having been adopted voluntarily, it is likely to be approached with greater motivation and goodwill than state-imposed pro bono work would be.

140 Jeremy Sarkin argued at the 'Pro Bono Conference' in Boksburg in May 2002 that attorneys should use their opportunity to adopt a programme on their own terms, before the state imposed one. Whittle (note 11 above) 13.

141 Cardin and Rhudy (note 55 above) 9. The pro bono programme in Maryland in the United States of America in the 1990s provides a useful comparison, because of the similarity in the scale of the attorneys' profession in Maryland and South Africa. In 1990, Maryland had 13 695 attorneys, while South Africa currently has about 14000.

142 The specific proposal of 48 hours per year was made by Cheryl Loots in a 'Discussion Paper on the Transformation of the Legal Profession' prepared by the Policy Unit of the Department of Justice and Constitutional Development 1999.

143 Unpublished Community Service Questionnaire (note 131 above), para 5. 


\section{(b) Compulsory community service for law students and graduates}

Two distinct proposals have been made and debated recently: ${ }^{144}$

(i) community service for LLB students as part of their curriculum; and

(ii) post-graduation community service.

The two proposals are not necessarily mutually exclusive, and might well complement one another. They will, however, be considered separately. In an article on legal education, Justice O'Regan argues that the primary social responsibility of law schools is to produce competent graduates. ${ }^{145}$ But, as she acknowledges, ${ }^{146}$ law schools have another responsibility: producing socially responsible law students, which, in my view, is equally important.

\section{(i) Community service for LLB students as part of their curriculum}

Certainly, law clinic work would be at the core of any proposed community service for law students. There are growing calls worldwide for the introduction of 'Clinical Legal Education' to supplement traditional methods of teaching law students, namely the 'lecture' and 'Socratic' methods. ${ }^{147}$ Rahman, speaking of the Bangladeshi experience, describes such traditional methods of classroom teaching as an attempt to convert the law into 'a mere totality of norms applicable to certain defined facts and situations', which overlooks 'the social values of law'. ${ }^{148}$ The advantages of a clinical legal education include the development of graduates who are more 'practical' and more 'ethical', ${ }^{149}$ as well as meeting what is a dire national need for legal aid services.

In the Ministry of Justice and Constitutional Development's 1999 Discussion Paper, Professor Loots proposed that law students should be required to complete 200 hours of community service as part of the curricular requirements of the LLB degree. ${ }^{150}$ The service could include work at law clinics, advice offices and Street Law teaching. ${ }^{151}$

This proposal was initially included in early drafts of the Legal Practice Bill. However, apparently after lobbying from the deans of law faculties,

144 Loots (note 142 above) 18.

145 O'Regan (note 84 above) 244.

146 Ibid 249.

147 J Asiema and L McKinney 'The Clinical Programme of the Faculty of Law, University of Nairobi: A Hybrid model' 2003 Discussion paper submitted for the First All-Africa Clinical Legal Education Colloquium 23 to 27 June 2003, Durban, South Africa 18.

148 M Rahman 'From Traditional to Rebellious to Developmental Lawyering: Tortuous Journey of Clinical Legal Education in Bangladesh' 2003 Discussion paper submitted for the First All-Africa Clinical Legal Education Colloquium 23 to 27 June 2003, Durban, South Africa 1.

149 Edwards (note 125 above) 38.

150 Loots (note 142 above) 18.

151 Ibid. 
it was removed. Nevertheless, many law schools have implemented compulsory community service as a curricular requirement. For instance, at the Universities of the Witwatersrand, Rhodes and North West, participation in legal aid clinics takes the form of a compulsory final year LLB course. This is not necessarily immediately achievable at all 21 law schools because of lack of capacity to provide the necessary resources and supervision.

The total AULAI Trust funding to university law clinics for 2004 was R3 125 529, spread over 15 institutions, ${ }^{152}$ which comes to an average of approximately R200 000 per institution. From this AULAI funding, the salaries of 13 attorneys, 16 candidate attorneys, 13 paralegals/administrative staff are paid. However, clinics also receive funding from other NGOs. ${ }^{153}$ In addition, justice centres have co-operation agreements with a number of universities to assist specific groups. ${ }^{154}$ These additional funders fund separate legal staff.

The number of students involved in these clinics varies from one institution to the next. The total number of students involved in law clinics in 2003 was about 1500 . Some institutions require 100 per cent of final year students to participate, ${ }^{155}$ while at others the rate is below 20 per cent. Approximately 63 legal staff were employed to supervise these students. Supervisor-student supervision ratios vary from 1:7 to 1:72. Once a supervision ratio rises above 1:25, depending on case load and other variables, it is problematic. Simply making clinic participation compulsory without any sensitivity to supervision ratios will only lead to poor legal services being rendered and students learning less than they would if properly supervised.

If finally achieved, however, compulsory curricular legal aid would see the almost 3000 final year students at South Africa's law schools rendering a valuable service, while also receiving the tangible benefit of a practical legal education. In reference to clinical education at the University of Zimbabwe, Guni states that students involved in the Legal Aid Clinic 'full time ... have started on a better footing in private

152 Since the mergers of academic institutions, the number of universities in the country has decreased, but some of these merged institutions now have two law faculties and consequently two law clinics. The statistics in this paragraph and the paragraph below are drawn from a document distributed at a meeting of the South African Law Deans Association on 14 May 2004. I am grateful to Ms Bev Bird, the Acting Director of the University of Cape Town Legal Aid Clinic for providing me with the statistics.

153 Other sources of funding include the Attorneys Fidelity Fund, Universities themselves, Atlantic Philanthropies and the Rural Legal Trust.

154 See the Legal Aid Board Annual Report 2002/3, the back cover of which lists these cooperation agreements.

155 In 2003, this was achieved at the University of Port Elizabeth, Rhodes University, University of Venda, University of the North, Rand Afrikaans University and University of Zululand. 
practice and government service than their counterparts who did not attend the Clinic'. ${ }^{156}$

Another target is the introduction of Student Practice Rules. These rules would allow final year law students acting through university law clinics to appear in magistrates' courts. Once a popular proposal, they have never been promulgated. ${ }^{157}$ The concern is, of course, that sufficient safeguards must be in place to prevent poor service by these students.

The Dean of the University of Cape Town's Faculty of Law has recently proposed the introduction of a curricular community service requirement for the LLB at that institution. ${ }^{158}$ In the case of legal aid clinic and advice office work, such a policy is most valuable in the latter years of the LLB degree. It would be irresponsible and counterproductive to allow unqualified students to provide such services. However, there are community-based projects that could be quite easily undertaken by first and second year students, given sufficient supervision and administrative support, for example Street Law teaching, which is particularly effective at the University of KwaZulu-Natal. ${ }^{159}$ Students travel to local schools, churches and other community fora to conduct lessons or workshops on aspects of the law.

The introduction of a compulsory community service component into the curriculum of the LLB degree nationally would create the human raw materials for a number of projects. The policy could be shaped to cater for students at different stages in the degree, for example by limiting law clinic work to final year students with the requisite legal knowledge, while allowing more junior students to participate in legal education projects such as Street Law. Other work that could be undertaken includes assisting in the running of the Small Claims Courts, domestic violence counselling and work at advice offices, which does not require the substantive knowledge of the law that law clinic work demands, and so could be undertaken by students in lower years.

All these possible community service projects would contribute greatly to the broad goal of access to civil justice. Increasing the number of students involved in university law clinics would create greater capacity to assist people with civil matters. Other projects, such as Street Law, would help to foster a human rights culture and make people more aware of their rights. More specialised projects, such as domestic violence advice work, target specific areas of law, both criminal and civil, in which

156 V Guni 'Understanding Clinical Legal Education with Special Reference to Zimbabwe' 2003 Discussion paper submitted for the First All-Africa Clinical Legal Education Colloquium 23 to 27 June 2003, Durban, South Africa 5.

157 McQuoid-Mason (note 6 above) fn 82.

158 Prof Hugh Corder, Dean of the Law Faculty of the University of Cape Town, announced this proposal at a general meeting of UCT law students in April 2003.

159 McQuoid-Mason (note 6 above) S-140-141. The University of KwaZulu-Natal has for many years required all final year LLB students to do a compulsory public interest law course consisting of either law clinic or Street Law work. 
there is a need for assistance. Such a package of community service nationally would have enormous benefits.

In the context of community service generally, two important potential pitfalls need to be avoided: first, creating projects that attempt to render a service without having sufficient supervision and administrative support to guarantee quality; secondly, encroaching on an often ignored but also scarce resource, namely student time. ${ }^{160} \mathrm{~A}$ community service programme should not come at the expense of unrealistically increasing the academic burden on students and thereby risking increased failure rates. As such, any community service programme would need to be carefully incorporated into current curricula. ${ }^{161}$

Discussing law clinic work specifically, as part of the broader proposal of community service, Wilson identifies three possible obstacles to the implementation of a 'clinical programme' at a law school. First, there is the ideological obstacle of conservative views as to the law school classroom experience. Secondly, there are institutional limits in terms of availability of funding and human resources. Finally, there are logistical limits, such as availability of office space and accessibility of the courts. ${ }^{162}$ If the first obstacle is overcome, and the profession is won over to a Clinical Legal Education approach, institutional and logistical obstacles, which differ across the institutions, need not be insurmountable.

In terms of costs, an advantage of an intra-curricular community service model is that it provides essentially free labour. The expenses involved generally pertain to administrative costs for the universities concerned. Indeed, rather than regarding the 'resources argument' as an obstacle to a community service programme, McQuoid-Mason notes:

What sets developing countries apart from developed countries is that law schools in the former have a special duty to serve their communities. . . because they often operate as a privileged island of resources in a sea of scarcity, particularly when it comes to providing access to justice for the poor. ${ }^{163}$

Therefore, while universities may initially experience difficulties in funding community service projects, particularly law clinics, they are in a better position to bear this cost than the communities in which they are located and which they should serve. When one combines this relative

160 'SPR Dialogue with D J McQuoid-Mason at the South Africa Law Teachers' Conference' Unpublished interview with David McQuoid-Mason conducted by two Harvard law students, Ryan Baker and Raj Goyle January 11 1999, Vista University, Bloemfontein.

161 O'Regan (note 84 above) 242.

162 R Wilson 'Clinical Legal Education for Human Rights Advocates' 2003 Discussion paper submitted for the First All-Africa Clinical Legal Education Colloquium 23 to 27 June 2003, Durban, South Africa 2.

163 D McQuoid-Mason 'Access to justice and the Role of Law Schools in Developing Countries: the South African Experience' 2003 Discussion paper submitted for the First All-Africa Clinical Legal Education Colloquium 23 to 27 June 2003, Durban, South Africa 46. 
privilege of law schools with a paradigm shift to regard Clinical Legal Education as part of the core curriculum of a law degree, then university law clinics must climb the ranks of internal funding priorities within universities. Reallocating some working hours of existing academic staff away from academic courses to clinic work would be one possible way of addressing the heavy costs of clinical programmes resulting from the intensive supervision required.

\section{(ii) Post-graduation community service}

Former Chief Justice Arthur Chaskalson is a proponent of compulsory community service for law graduates. ${ }^{164}$ The graduates would be registered as 'legal interns' and would perform a certain period, perhaps a year, of service in mainly state legal aid structures as a requirement for entry into the profession. This would be similar to the period of internship which medical graduates are currently required to undergo in South Africa. Current competing drafts of the Legal Practice Bill empower the Minister for Justice and Constitutional Development to promulgate regulations to impose compulsory community service as a requirement for entry into the legal profession. ${ }^{165}$ However, it is not clear which version of the Bill will become law, or how (or even whether) the Minister will exercise this regulation-making power.

Two main advantages of such a programme are cited: first, an obvious increase in the available human resources for the provision of civil legal aid, and second, the provision of an egalitarian across-the-board entrypoint into the legal profession. The second argument is the factual observation that the current system of articles of clerkship constitutes a barrier to access to the profession, particularly for previously disadvantaged students. ${ }^{166}$ While about 2500 lawyers graduate annually, there are fewer than 2000 registered candidate attorneys (CAs). ${ }^{167}$ Given that most CAs take articles of clerkship for two years, this means that probably no more than 1000 new posts are available each year for approximately 2500 incoming graduates. A compulsory, across-theboard system of community service would provide an entry point into the profession for all graduates. It should be noted, however, that not all law graduates seek articles of clerkship, as many do not intend to practise as attorneys. It might be necessary, therefore, to limit such a system to those graduates who intend to practise.

Another 'advantage' of a post-graduation programme is that it would ensure that law graduates give back to the state, which heavily subsidises

164 A Chaskalson 'Legal Interns Could Solve Legal Aid Problems' De Rebus (December 1997) 782.

165 See s 8 of the Law Society Proposal and s 30 of the Task Team Proposal.

166 McQuoid-Mason (note 6 above) S139.

167 O'Regan (note 84 above) 242. 
a legal education. ${ }^{168}$ If any simple justification were required for the imposition of compulsory work on graduates, this is found in the fact of state subsidies ultimately gleaned from the taxpayer.

This proposal met with much criticism from the attorneys' profession. It was argued in an editorial in the profession's magazine De Rebus that representation by such legal interns could be of such a poor standard that it would almost be worse than no representation. ${ }^{169}$ It was argued further that the legal aid system should not be used as a means of granting entry into the profession to disadvantaged students, as that is not its purpose. $^{170}$

There is a genuine concern that unsupervised legal interns could struggle to such an extent that both the clients and the interns would be dissatisfied. In the medical internship programme, many interns have felt as if they have been 'thrown in at the deep end'. This would have to be avoided to prevent internship picking up a negative stigma as chaotic and frustrating for the interns and 'second-rate justice' for their clients.

However, the introduction of justice centres provides a useful framework within which to implement such a programme. As the Board had established 58 urban and 27 satellite offices and 13 High Court units by the end of $2004,{ }^{171}$ combined with the existing 21 university clinics and various pilot rural projects, well over 100 stations for the placement of interns should be in place by 2005 . This would mean placing about 20 of the 2500 graduates at each station. In reality, not all 2500 would be available, as some graduates do not seek to enter the mainstream profession immediately. To reduce this number further, interns could be placed at the offices of the Public Defender. Indeed, 390 of South Africa's 432 magistrates' courts have facilities where people can apply for legal aid. ${ }^{172}$ The Department could sift these potential placement centres to include only those where sufficient supervision is available. A further possible placement is as a judge's clerk, researcher or associate at the High Courts, Labour Courts, Supreme Court of Appeal and Constitutional Court. These posts already exist, all that would be required would be to recognise them as community service placements.

As McQuoid-Mason notes, the implementation of such a programme will not be easy. The budgetary implications are huge. The salaries of the 2500 -odd interns, in order to be reasonable, would have to be in the region of R3 000 per month, which would come to a total of about R90million per annum. Nevertheless, there may actually be indirect cost benefits to increasing access to civil legal resources. Because lawyers are generally inclined to settle matters out of court, civil suits in which one

168 Sarkin (note 10 above) 227.

169 Referred to, unreferenced, in McQuoid-Mason (note 6 above) S-139.

170 Ibid.

171 Legal Aid Board (note 5 above) 17 Table 1.

172 Legal Aid Board Business Plan (note 69 above) 20. 
party is unrepresented are more likely to go to court. As such, increasing access to civil legal assistance may relieve some of the pressure on the courts, which translates into reduced expenses for the state. However, this indirect benefit is unlikely to offset fully the expense of introducing such an internship programme, and the financial implications may currently be prohibitive.

\section{CONCLUSION}

At present, the South African courts are open to anyone, just like the Ritz Hotel! The commercial industry simply does not serve the vast majority of the population. There is good reason to "mourn the rise of materialism in law firms and the dominance of intense theoretical abstraction in elite law schools'. ${ }^{173}$ In a profession that claims to be the mechanism for the delivery of social justice, such a position is not tenable in the long term.

Section 34 of the Constitution guarantees a fair civil trial. I argue that this confers a right on civil litigants to free representation in at least some civil matters, depending on the capacity of the litigant to represent him or herself and the complexity and potential consequences of the litigation. This imposes on the state an obligation to implement a comprehensive plan to provide civil legal aid to those entitled to it. Resource constraints may currently mean that its failure to provide civil legal aid to the extent required by s 34 is a reasonable limitation of the s 34 right. Nevertheless, the state might look to the legal profession to assist in meeting its constitutional obligations.

Bengtsson observes that the South African government is unable to operate in isolation from civil society and NGOs. ${ }^{174}$ While it is clear that the state structures, particularly the Legal Aid Board, are currently overwhelmed, in my view the responsibility for the provision of civil legal aid lies somewhere other than at the feet of the various fragmented NGOs. Although the NGOs make a valuable contribution to the development of our jurisprudence, they are too limited to meet the country's civil legal aid needs. Rather, the responsibility to assist the state should fall squarely on the mainstream profession: attorneys, law students and, by extension, universities, especially state universities.

Compulsory pro bono for attorneys has been hotly debated, and the Cape Law Society has taken the lead, developing a model requiring attorneys to provide two hours of service each month. While the Cape model is not flawless, it offers a programme that can be tested and modified and has the major advantage that it is a voluntary move.

The incorporation of compulsory community service into the LLB degree would also greatly benefit both students and the broader community. Compulsory law clinic work for final year students would 
be an important aspect of such a programme, but it could also involve community education projects such as Street Law.

An internship programme upon graduation would also have a number of benefits, providing a uniform bridge into the profession for graduates and a vast human resource for the provision of legal aid. However, it may currently be a prohibitively expensive project, and the necessary infrastructure to provide so many internship placements may be lacking.

Some form of broad, institutionalised programme for the provision of free civil legal services by lawyers and law students is necessary to redeem the profession and the law as an institution, and allow constitutional promises to materialise in the lives of the many. Otherwise, civil litigation will remain not an instrument for but an obstacle to the pursuit of substantive equality. 